\title{
2022 Update to state of the journal of patient-reported outcomes
}

\author{
Ron D. Hays ${ }^{1 *}$ (D) and Chih-Hung Chang ${ }^{2}$ (D)
}

The Journal of Patient-Reported Outcomes (JPRO) is an international, open access, multi-disciplinary journal publishing original research and review articles, brief communications, commentaries, editorials, and reviews of recent books and software advances in the field of patient-reported outcomes. The JPRO is an official journal of the International Society for Quality of Life Research (ISOQOL). The first JPRO articles were published on September 12, 2017.

We want to acknowledge the immense contributions of Dennis Revicki, JPRO Founding Co-Editor-in-Chief, who died on May 9, 2021. His impact on ISOQOL and the field of patient-reported outcomes was immense. We miss him greatly.

The fifth year (2021) of the JPRO was another successful one due to the contributions made by reviewers and the consistently high quality of the science reflected in the published articles. We are also extremely grateful for the conscientious work of the associate editors: Jill Carlton (University of Sheffield, UK), Joanne Greenhalgh (University of Leeds, UK), John Devin Peipert (Northwestern University, USA), Caroline Potter (University of Oxford, UK), and Jessica Roydhouse (University of Tasmania, Australia).

We are confident in a very positive trajectory for the JPRO in 2022 and we encourage those conducting patient-reported outcomes research to submit manuscripts and to serve as peer reviewers.

Sincerely,

Ron D. Hays and Chih-Hung Chang

JPRO Co-Editors-in-Chief
Authors' contributions

Both authors read and approved the final manuscript

\section{Declarations}

Competing interests

The authors declare that they have no competing interests.

\section{Author details}

${ }^{1}$ University of California, Los Angeles, USA. ${ }^{2}$ Washington University School of Medicine, St. Louis, USA.

Received: 30 December 2021 Accepted: 30 December 2021 Published online: 12 January 2022

\section{Publisher's Note}

Springer Nature remains neutral with regard to jurisdictional claims in published maps and institutional affiliations.

*Correspondence: drhays@ucla.edu

${ }^{1}$ University of California, Los Angeles, USA

Full list of author information is available at the end of the article

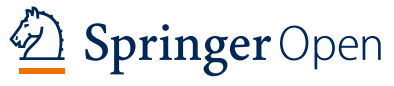

(c) The Author(s) 2022. Open Access This article is licensed under a Creative Commons Attribution 4.0 International License, which permits use, sharing, adaptation, distribution and reproduction in any medium or format, as long as you give appropriate credit to the original author(s) and the source, provide a link to the Creative Commons licence, and indicate if changes were made. The images or other third party material in this article are included in the article's Creative Commons licence, unless indicated otherwise in a credit line to the material. If material is not included in the article's Creative Commons licence and your intended use is not permitted by statutory regulation or exceeds the permitted use, you will need to obtain permission directly from the copyright holder. To view a copy of this licence, visit http://creativecommons.org/licenses/by/4.0/. 